\title{
低水流出に適用する貯留関数式の定数の特性 PROPERTIES OF PARAMETERS IN STORAGE FUNCTION EQUATION USED FOR LOW FLOW
}

\author{
藤村和正 1 ・井芹慶彦 2 ・鼎信次郎 3 ・村上雅博4 \\ Kazumasa FUJIMURA, Yoshihiko ISERI, Shinjiro KANAE and Masahiro MURAKAMI \\ 1正会員＼cjkstart博（工） 明星大学准教授 理工学部（广191-8506東京都日野市程久保2-1-1） \\ 2 正会員 博 (工) 東京工業大学産学官連携研究員 大学院理工学研究科 \\ ( (152-8550東京都目黒区大岡山2-12-1) \\ 3 正会員 工博 東京工業大学教授 大学院理工学研究科（广152-8550東京都目黒区大岡山2-12-1） \\ 4 フェロー会員 工博 高知工科大学教授 環境理工学群（广1782-8502高知県香美市土佐山田町宮ノ口185）
}

This study investigated the properties of low-flow parameters in storage function equation, of which represented by relation of exponential, using the hourly hydrological model for four mountainous basins. The $A_{u}-N$ exponential equation includes two parameters of $\alpha$ and $\beta$. The hydrological analysis was performed for selected six $N$ values in the range of 1 to $10^{5}$ with the range of $A_{u}$ value determined by trial and error. The result shows that parameter $\beta$ equaled to 1 , therefore the $A_{u}-N$ relationships were represented by inversely proportional equation. In addition, storage function equation can be expressed by only one parameter of $\alpha$, which is the specific value for each basin.

Key Words : low flow, mountainous basin, storage function equation, flow duration curve, hydrological analysis

\section{1. はじめに}

社会における水資源の重要性から，無降雨が長く続く ときの流出については，19世紀後半頃から研究が行われ ている. 低水流出の減水特性については初期の研究を含

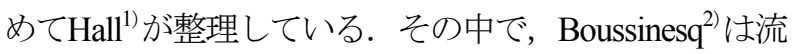
出を時間の関数として表し, Horton ${ }^{3)}$ は貯留量の関数と して表したことを記している. その後, これらの関数式 の研究が進められ，様々な形式の減水式が提案されてい

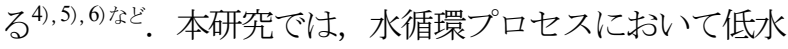
流出を重視し, Horton $^{3}$ により示された次に示寸流出量 一貯留量式を基礎として進める.

$$
Q=K S^{N}
$$

ここに, $Q$ : 流量, $S$ : 貯留量, $K:$ 定数, $N$ : 指数.

山地流域を対象とした水循環解析において安藤ら ${ }^{7), 81}$ は, Ding) が水理学的な考察から示した次の不圧地下水流出 の貯留関数式を適用している.

$$
Q_{g}=A_{u}^{2} S_{g}^{2}
$$

ここに, $Q_{g}$ : 地下水流出量, $A_{u}$ : 定数, $S_{g}$ : 地下水貯留
量. (2)式は(1)式の指数 $N$ 乗を二乗とし, 定数 $K$ を $A_{u}{ }^{2}$ で表 した式である. 近年, Ding ${ }^{9)}$ は, $N$ 乗とした(3)式に示す 貯留関数式を再び提案し, 短期の流出イベントを対象に してM值を 1 から3程度の值で示している.

$$
Q_{g}=A_{u}{ }^{N} S_{g}{ }^{N}
$$

Fujimura et $a l^{10}{ }^{10}$ は, 安藤ら ${ }^{8}$ の水循環モデルにいくつか の改良を加え, 早明浦ダム流域を対象に水循環解析を 行った. その結果, 概水再現性は得られたものの, 低流 出部では解析值は実測值に対して差異が見られた. そこ で著者ら ${ }^{11)}$ は低水流出の貯留関数式の再検討が必要であ ると考え，(3)式を用いて早明浦ダム流域と白川ダム流域 を対象に7, 900回の水循環解析を行い, $A_{u}$ とNの最適值の 探索を行った. 得られた結果は, 解析誤差の最小值近傍 に現れる $A_{u}-N$ 関係は指数関数で表されること，つまり， $\alpha$ と $\beta$ を定数とする次式で表されることである.

$$
A_{u}=\frac{1}{\alpha N^{\beta}}
$$

指数 $N$ に着目すると, 探索範囲 1 ～40における最適值は, 早明浦ダム流域では 39.5 , 白川ダム流域では 40.0 となり

高位の值として現れた．また，探索範囲を1〜100に拡張 した同様の解析 ${ }^{12)}$ でも，早明浦ダム流域では100.0，白川 
ダム流域では70.0となり最適な $N$ 值は高位に表れた.こ の理由は, Smakhtin ${ }^{13)}$ が指摘しているように, 低水流出 は長期間に流域内で発生する様々な複雑な自然現象が集 約された結果であり，非線形性が強いことが考えられる。 著者らの研究から生じた課題は, 指数を $N$ 乗とする貯留

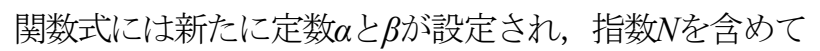
貯留関数式の定数が3つに増えたことである. そしてこ の3つの定数の特性が明らかでないことである。これは 将来的な実用を考えると困難さが残る。そこで本研究で は, 前報 ${ }^{11)}$ と同様の水循環解析による最適定数の感度分 析に基づき, 対象流域を 2 流域から 4 流域に増やし, 指数 $N$ の探索範囲を $1 \sim 10^{5}$ まで拡張し, $A_{u}$ と $N$ の最適值探索 を効率的に行い，低水流出を対象とした貯留関数式の定 数の特性を示寸とともに，実用に向けた貯留関数式を提 案することを目的とする.

\section{2. 対象流域}

\section{（1）流域の概要}

対象流域は, 四国地方の吉野川上流の早明浦ダム流域 と早明浦ダム流域内の瀬戸川流域，および東北地方の最

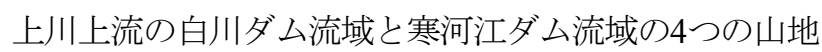
河川流域とする. 図-1には流域の概要図を示す.

早明浦ダム流域（流域面積 $472 \mathrm{~km}^{2}$ ) は四国の重要な水 源であり，下流の池田ダムとの連携操作によって高度な 水利用が行われている。瀬戸川流域（流域面積 $53.7 \mathrm{~km}^{2}$ ) は，早明浦ダム流域内の高知分水施設の一つである瀬戸 川取水堰までの流域とする. 高知分水は鏡川流域一流域 変更を行い, 高知市に水道用水を供給している. 白川ダ 么流域（流域面積 $206 \mathrm{~km}^{2}$ ) と寒河江ダム流域（流域面積 $233 \mathrm{~km}^{2}$ ) は，東北地方の最上川の上流支川の置賜白川と 寒河江川の上流に位置し, 河川水は主に農業用水に利用 されている. この $2 つ の$ 流域は, 冬季の大陸性季節風の 影響が強い日本有数の豪雪地帯にある.

20 万分の 1 日本シームレス地質図から各流域の表層地 質を読み取り，地質年代の面積率を表-1に表した．早明 浦ダム流域と瀬戸川流域は，ほぼ中生代の変成岩類が占 めている. 白川ダム流域は, 新第三紀と古第三紀の火山 性地質が卓越している. 寒河江ダム流域は, 中生代の深 成岩類が多いが，新第三紀，第四紀地質も含まれており， 白川ダム流域とは異なる複雑な地質構成となっている.

\section{（2）水文データ}

使用する水文データは1時間単位の降水量, 流出量, 気温データであり, 対象期間は早明浦ダム流域と瀬戸川 ダム流域では，1991年1月1日から2010年12月31日までの 20 年間, 白川ダム流域と寒河江ダム流域では, 2003年10 月1日から2013年9月30日までの10年間である，早明浦ダ ム流域の降水量, ダム流入量データおよび頼戸川取水堰
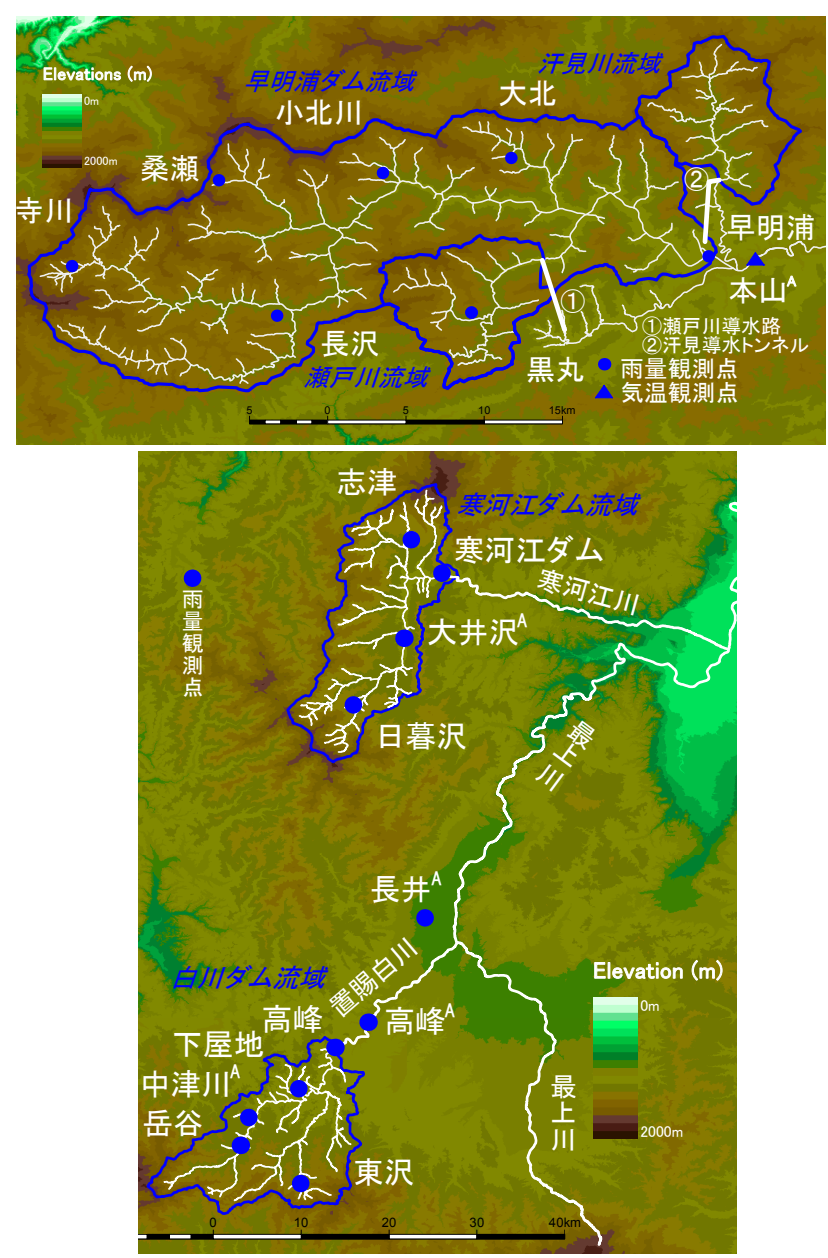

図-1 対象流域の概要図

表-1 流域の地質年代の面積率

\begin{tabular}{|c|c|c|c|c|c|}
\hline & 第四紀 & 新第三紀 & 古第三紀 & 中生代 & 合計 \\
\hline 早明浦ダム & $1.8 \%$ & $0.0 \%$ & $0.5 \%$ & $97.7 \%$ & $100.0 \%$ \\
\hline 瀬戸川流域 & $0.9 \%$ & $0.0 \%$ & $0.0 \%$ & $99.1 \%$ & $100.0 \%$ \\
\hline 白川ダム & $2.4 \%$ & $87.2 \%$ & $9.4 \%$ & $1.0 \%$ & $100.0 \%$ \\
\hline 寒河江ダム & $14.4 \%$ & $32.4 \%$ & $2.9 \%$ & $50.3 \%$ & $100.0 \%$ \\
\hline
\end{tabular}

\begin{tabular}{|c|c|c|c|c|c|c|c|c|}
\hline \multirow[b]{2}{*}{ 부 } & 表-2 & 各観浿 & 点の & 毛降水量 & =年流出 & 量 & 単位:mm) & \\
\hline & 寺川 & 3,448 & \multirow{2}{*}{ 息 } & 高峰 & 2,568 & \multirow{2}{*}{$\begin{array}{l}\text { 寒 } \\
\text { 江 } \\
\text { 盗 }\end{array}$} & 志津 & 3,009 \\
\hline \multirow{2}{*}{ 琞 } & 長沢 & 3,735 & & 下屋地* & 2,126 & & 寒河江 & 2,696 \\
\hline & 桑瀬 & 2,848 & 隹 & 中津川| & 2,653 & \multirow{2}{*}{$\begin{array}{l}\text { 多 } \\
\text { 流 } \\
\text { 域 }\end{array}$} & 日暮沢* & 2,442 \\
\hline \multirow[t]{2}{*}{ 流 } & 小北川 & 3,056 & 域 & 岳谷* & 2,437 & & 大井沢A & 2,727 \\
\hline & 黒丸 & 3,479 & \multirow{2}{*}{$\begin{array}{l}10 \\
\text { 年 } \\
\text { 坢 }\end{array}$} & 東沢* & 1,345 & & 流出高 & 3,804 \\
\hline \multirow{2}{*}{$\begin{array}{l}20 \\
\text { 年 } \\
\text { 平 }\end{array}$} & 大北 & 2,841 & & 流出高 & 2,484 & $\begin{array}{l}10 \\
\text { 年 } \\
\text { 間 }\end{array}$ & \multirow{3}{*}{\multicolumn{2}{|c|}{$\begin{array}{l} \\
\text { A:AMeDASデータ } \\
\text { *:期データ不良 }\end{array}$}} \\
\hline & 早明浦 & 2,745 & \multirow{2}{*}{ 均道 } & \multirow{2}{*}{\multicolumn{3}{|c|}{$\begin{array}{l}\mathrm{A}: \mathrm{AMeDAS} \text { データ } \\
\text { *:冬期データ不良 }\end{array}$}} & & \\
\hline 壃 & 流出高 & 2,158 & & & & 檤 & & \\
\hline
\end{tabular}

地点の高知分水への導水量データは水資源機構から提供 を受けた。瀬戸川取水堰は固定堰であるため，導水量は 最大で $4.4 \mathrm{~m}^{3} / \mathrm{s} （ 7.08 \mathrm{~mm} /$ day $)$ である. 気温データは本山 地点のAMeDASデータを用いた. 白川ダム流域, 寒河江 ダム流域の各種データは水文・水質データベースおよび AMeDASデータから取得した. データは主管機関で照査 され，信頼性を有していることを前提とした．冬期に欠 測となる地点の降水データは, 流域内の有効な他の地点 のデータを適用した.

(a) 年降水量と年流出量 
(a) 早明浦ダム流域 1991/1/1 2010/12/31

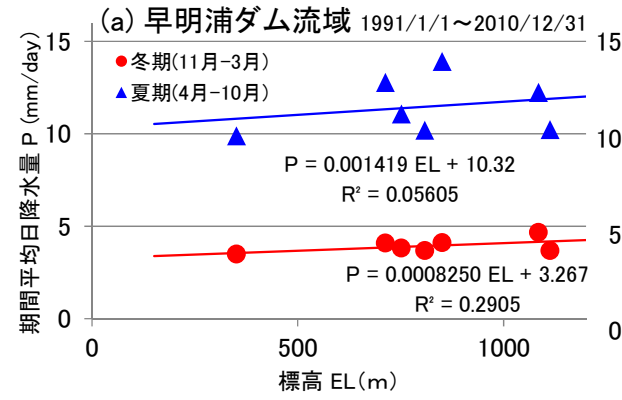

(b) 白川ダム流域 2003/10/1 2013/9/30

(c) 寒河江ダム流域 2003/10/1 2013/9/30
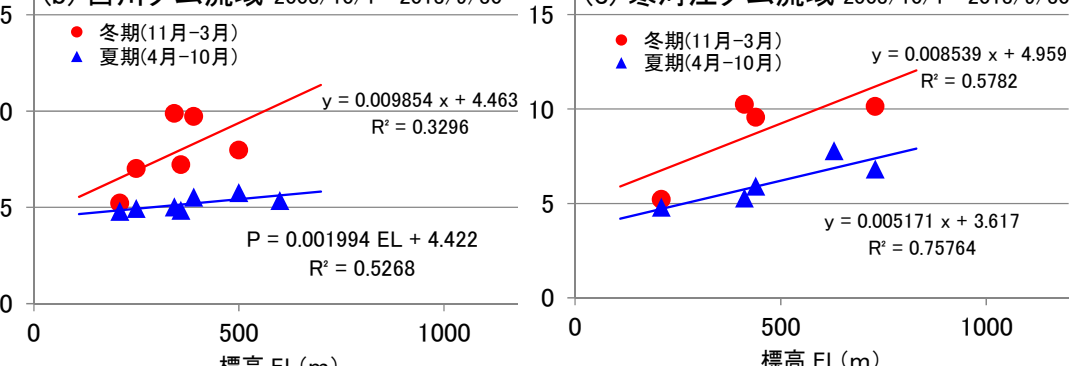

図-2 対象流域の標高-降水量の関係

各観測点の期間平均の年降水量と年流出量を表-2に示 す. 早明浦ダム流域の年降水量は $2,841 \mathrm{~mm} \sim 3,735 \mathrm{~mm}$, 平均值は3,165mmで年流出量 $2,158 \mathrm{~mm}$ より約 $1,000 \mathrm{~m}$ 大き い. 前報で示した早明浦ダム流域の 20 年間の年水収支に おいて ${ }^{11)}$ ，年蒸発散量448mm以外の損失量が $612 \mathrm{~mm}$ であ り，早明浦ダム流域は石灰質変成岩が支配的であること から，地下水貯留量の漏出が考えられる．白川ダム流域 の冬期不良観測点を除いた年降水量は，高峰2,568mm, 中津川2,653mmで，その平均值2,611 mmは年流出量 $2,484 \mathrm{~mm}$ より $127 \mathrm{~mm}$ 小さい. 冬季降水量の標高依存性を 考慮すると流域年降水量は水収支的に妥当な值であると 思われる ${ }^{11)}$. 寒河江ダム流域の年降水量は2,696mm〜 $3,009 \mathrm{~mm}$ 範囲で平均值は2,811mmである。これは年流 出量3,804mmを約 $1,000 \mathrm{~mm}$ も下回っている.この理由と して, 冬季降水量の正確な補足が困難なことや，古・中 生層が50\%以上を占め，透水層の地層の走向が流域表面 の傾斜と一致しておらず，流域外からの浸入量が存在す る可能性などが考えられる.

(b) 季節別の標高と降水量の関係

各流域の標高 - 降水量関係を冬期と夏期に分けて図-2 に表した。降水量は期間平均の日降水量（mm/day）で ある.なお，白川ダム流域と寒河江ダム流域には，標高 の低い地点として流域外のAMeDAS長井の降水量を含め ている．標高 - 降水量関係を直線近似したところ概ね正 の相関が見られた．特に積雪域である流域は，冬期の近 似直線の傾きが大きい. 各流域の標高 - 降水量直線の傾 きは水循環解析で流域降水量の算定に用いている.

(c) 流況曲線

4流域の実測の流況曲線を図-3に示す。横軸は対象期 間全日数を百分率で表した経過日数割合（\%) である. 表-3には15\%流量，97\%流量とその平均值を示す. $15 \%$ 流量を見ると寒河江ダム流域の值が特に大きい.

\section{3. 方法}

\section{（1）水循環モデル}

本研究で用いる水循環モデルは, 前報 ${ }^{11)} て ゙$ 紹介した山 地河川流域に適用してきた水循環モデルである. その構 造は，流域平均降水量の推定，Diskin-Nazimovモデルに よる直接流出量と雨水浸透量の算定, 安藤ら ${ }^{7)}$ の手法に

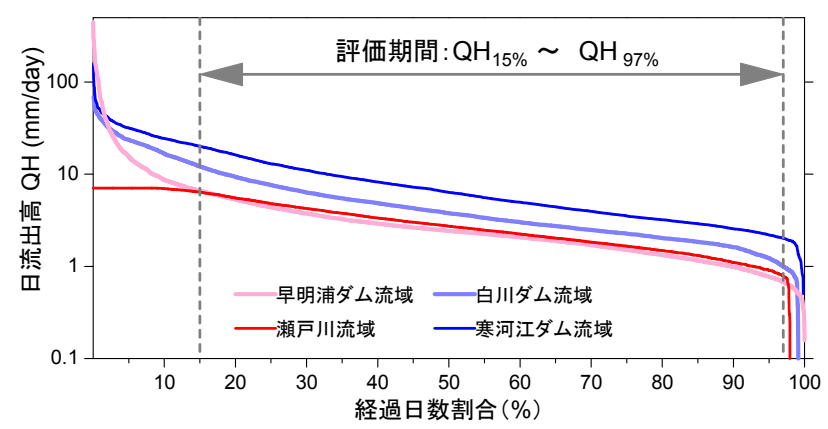

図-3 各流域の流況曲線

表-3 経過日数割合の流出高と平均値(単位: $\mathrm{mm} / \mathrm{day}$ )

\begin{tabular}{|c|c|c|c|c|}
\hline 流域名 & $\begin{array}{c}\text { 対象期間 } \\
\text { (年数, 日数) }\end{array}$ & $\mathrm{QH}_{15 \%}$ & $\mathrm{QH}_{97 \%}$ & $\underset{(15 \%-97 \%)}{\mathrm{QH}_{\text {ave. }}}$ \\
\hline 早明浦ダム & \multirow{2}{*}{$\begin{array}{c}\text { 1991.1.1-2010.12.31 } \\
\text { (20年間, 7,305日) }\end{array}$} & 6.5962 & 0.6771 & 2.526 \\
\hline 瀬戸川 & & 6.39 & 0.77 & 2.778 \\
\hline 白川ダム & \multirow{2}{*}{$\begin{array}{c}2003.10 .1-2013.9 .30 \\
\text { (10年間, 3,653日) }\end{array}$} & 12.12 & 0.99 & 4.139 \\
\hline 寒河江ダム & & 20.054 & 2.013 & 6.970 \\
\hline
\end{tabular}

よる不飽和帯水分量, 地下水涵養量と地下水流出量の算 定，貯留関数法を用いた洪水流出量の算定からなり，地 下水流出量と洪水流出量の和が総流出量となる. 詳細な 説明は本稿では省略する.

\section{(2) 誤差評価式}

解析誤差の評価方法として, 当初, 以下に示す日流出 量相対誤差の平均值 (ADRE: Average of Daily runoff Relative Error）（\%）とNash指標（E）を考えた.

$$
\begin{gathered}
A D R E=\frac{\sum\left(\frac{\left|Q_{c a l}-Q_{o b s}\right|}{Q_{o b s}} \times 100\right)}{n}(\%) \\
E=1-\frac{\sum\left(Q_{o b s}-Q_{c a l}\right)^{2}}{\sum\left(Q_{o b s}-Q_{m}\right)^{2}}
\end{gathered}
$$

ここに, $Q_{c a l}$ : 日流出量計算值, $Q_{o b s}$ : 日流出量実測值, $Q_{m}$ : 流出量実測值の評価期間平均值, $n$ : 評価日数合計. 表-4に示す $A_{u}$ と $N$ を用いて早明浦ダム流域を対象に水循 環解析を行ったところ，Nash指標は，洪水流出を含む場 合（11)と(3)）では0.9以上となるが，低水流出（2)と(4) に対してはマイナス值となった. 一方, ADREは, 洪水 流出を含む場合も低水流出を対象にした場合も数值に大 きな差異は生じていない.Nash指標は式の構造が実測平 均值 $Q_{m}$ を分母としているため, 洪水から低水まで変動 幅が大きい現象と，低水流出の変動幅の小さい現象では， 
感度が異なると考えられる．本研究では，低水流出に対 して分かりや寸い評価值はADREであると見なし，誤差 評価関数として採用寸る. 評価対象期間は，全ての流域 で安定した流況が得られていることを勘案し，実測值の 経過日数割合 $15 \%$ 以上 $97 \%$ 未満の流量とした.

\section{(3) 最適定数の探索}

効率的な方法で最適值の探索を行う。つまり， $N$ 值を 1，2，10，100，10 ${ }^{3}, 10^{4}, 10^{5}$ に固定し，このN值に対 して試算によって $A_{u}$ 最適值が含まれる範囲を設定する. そして固定した $N$ 值に対して $A_{u}$ 值を変化させて水循環解 析を繰り返し，最適な $A_{u}-N$ 值の組み合わせを探索する

\section{4. 結果と考察}

\section{(1) 最適定数の探索結果}

選定した指数 $N$ に対する定数 $A_{u}$ の探索範囲, 計算数, $A_{u}$ 最適值および解析誤差ADREを早明浦ダム流域を例に 表-5に示寸． 前報 ${ }^{11)}$ では，水循環解析の計算数は合計 7,900計算であった. しかし，本研究では， $N$ 值の探索範 囲1 10 5 の中で計算対象の $N$ 值を6つ選定し， $A_{u}$ の探索範 囲を限定したため，計算数は合計295であった．N值の 探索範囲を拡張させる一方で計算数を大幅に減らすこと ができた．図-4に $A_{u}$ の探索範囲に対するADREの変化曲 線とその最小值を表す。各 $N$ 值に対してADREは下に凸 の曲線となり, $A D R E か ゙$ 極小になる点が $A_{u}$ の最適值であ る. 他の3流域についても同様の手法で最適定数を探索 した（表-6）。次に，早明浦ダム流域を例として，最小 のADREを得た $A_{u}-N$ 関係を図-5の両対数グラフに表す. $A_{u}-N$ 関係は，両対数グラフ上で $N$ 值が100以上の場合完 全相関であり, $A_{u}-N$ 最適值は近似直線上に存在寸る. しかし， $N=10(1 \mathrm{E}+01) の A_{u}-N$ 最適值は近似直線と若 干のズレが見られた. 従って, 他の3流域についても $N$ 值100以上の範囲において最小二乗近似を行った，その 結果，(4)式と同形の指数関数式を4流域において得た.

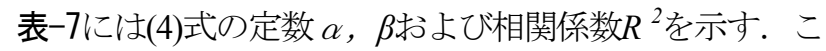
れらの結果から，最小誤差を得る $A_{u}-N$ 関係は，(4)式と 同様の指数関数式で表されることが追認できた.この理 由として, 貯留関数式 $Q_{g}=A_{u}{ }^{N} S_{g}{ }^{N}$ において $N$ 值の増加 に対して $A u$ 值が指数関数的に減少しないと $A_{u}{ }^{N}$ が非常に 大きな值となり，計算值 $Q_{g}$ が発散することになる，それ 故 $A_{u}-N$ 関係は指数関数式が成立すると考えられる.

\section{（2）実用的な低水流出の貯留関数式}

(4)式における定数及の值は，表-7に示すように，瀬戸 川流域と寒河江ダム流域では1であり, 他の2流域では 1.004 と1.005である.この結果から $\beta$ は1である可能性が 高く, そして $\beta$ は流域に依存しないことが考えられる. 従って, $\beta=1$ と見なすと $\alpha$ を唯一の定数とした指数 $N に$ 対
表-4 早明浦ダム流域での ADREとNash指数の比較

\begin{tabular}{|c|c|c|c|}
\hline$A_{u}$ 值, $N$ 值 & 評価範囲 & $A D R E(\%)$ & Nash指数 \\
\hline \multirow{2}{*}{$\begin{array}{c}N=2 \\
A_{u}=0.031\end{array}$} & (1) $\left.\mathrm{QH}_{(0 \%} \sim 97 \%\right)$ & 39.145 & 0.918 \\
\cline { 2 - 4 } & (2) $\mathrm{QH}_{(15 \% \sim 97 \%)}$ & 38.625 & -0.346 \\
\hline \multirow{2}{*}{$\begin{array}{c}N=100 \\
A_{u}=0.00031\end{array}$} & (3) $\mathrm{QH}_{(0 \% \sim 97 \%)}$ & 33.871 & 0.929 \\
\cline { 2 - 4 } & (4) $\mathrm{QH}_{(15 \% \sim 97 \%)}$ & 32.214 & -0.00372 \\
\hline
\end{tabular}

表-5 早明浦ダム流域の $M$ 值に対する $A_{u}$ 最適値の探索

\begin{tabular}{|c|c|c|c|c|c|}
\hline$N$ & $A_{u}$ 探索範囲 & ステップ值 & 計算数 & $A u$ 最適值 & $A D R E(\%)$ \\
\hline 1 & $0.06 \sim 0.30$ & 0.01 & 25 & 0.12 & 48.971 \\
\hline 2 & $0.015 \sim 0.064$ & 0.001 & 50 & 0.031 & 38.625 \\
\hline 10 & $0.0020 \sim 0.0060$ & 0.0001 & 41 & 0.0034 & 32.294 \\
\hline 100 & $0.00016 \sim 0.00064$ & 0.00001 & 49 & 0.00031 & 31.214 \\
\hline $10^{3}$ & $1.6 \times 10^{-5} \sim 5.5 \times 10^{-5}$ & $1.0 \times 10^{-6}$ & 40 & $3.0 \times 10^{-5}$ & 31.108 \\
\hline $10^{4}$ & $1.6 \times 10^{-6} \sim 6.5 \times 10^{-6}$ & $1.0 \times 10^{-7}$ & 50 & $3.0 \times 10^{-6}$ & 31.098 \\
\hline $10^{5}$ & $1.6 \times 10^{-7} \sim 5.5 \times 10^{-7}$ & $1.0 \times 10^{-8}$ & 40 & $3.0 \times 10^{-7}$ & 31.097 \\
\hline
\end{tabular}

表-6 その他流域のN值に対する $A_{\iota}$ 最適值

\begin{tabular}{ccccccc}
\hline \multirow{2}{*}{$N$} & \multicolumn{2}{c}{ 瀬戸川流域 } & \multicolumn{2}{c}{ 白川ダム流域 } & \multicolumn{2}{c}{ 寒河江ダム流域 } \\
\cline { 2 - 7 } & $A_{u}$ & $A D R E(\%)$ & $A_{u}$ & $A D R E(\%)$ & $A_{u}$ & $A D R E(\%)$ \\
\hline 1 & 0.055 & 78.586 & 0.084 & 42.022 & 0.056 & 31.636 \\
\hline 2 & 0.014 & 74.293 & 0.022 & 38.976 & 0.012 & 30.199 \\
\hline 10 & 0.0016 & 72.101 & 0.0027 & 37.004 & 0.0013 & 28.915 \\
\hline 100 & 0.00014 & 71.828 & 0.00025 & 36.601 & 0.00012 & 28.624 \\
\hline $10^{3}$ & $1.4 \times 10^{-5}$ & 71.798 & $2.4 \times 10^{-5}$ & 36.559 & $1.2 \times 10^{-5}$ & 28.607 \\
\hline $10^{4}$ & $1.4 \times 10^{-6}$ & 71.7954 & $2.4 \times 10^{-6}$ & 36.5546 & $1.2 \times 10^{-6}$ & 28.6055 \\
\hline $10^{5}$ & $1.4 \times 10^{-7}$ & 71.7951 & $2.4 \times 10^{-7}$ & 36.5542 & $1.2 \times 10^{-7}$ & 28.6053 \\
\hline
\end{tabular}

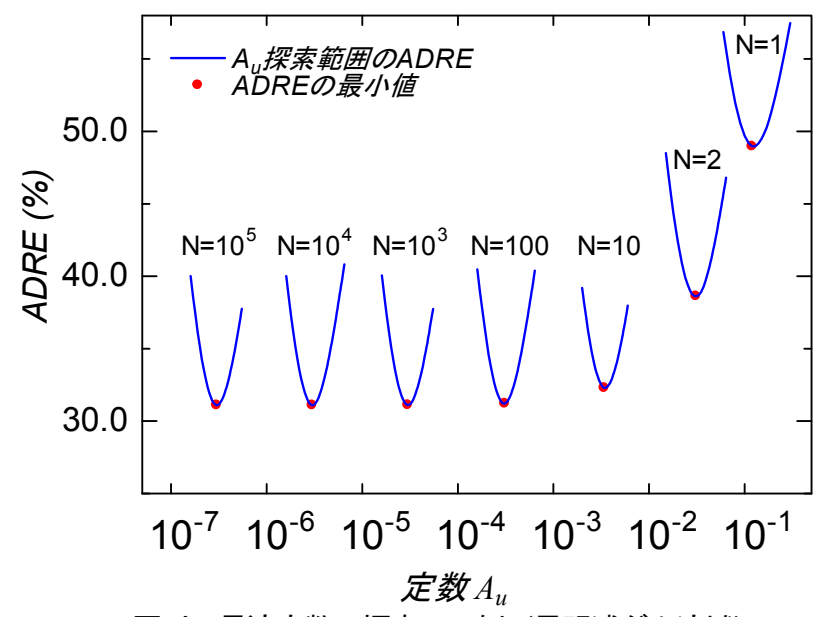

図-4 最適定数の探索の一例（早明浦ダム流域）

する $A_{u}$ の次に示す反比例式が得られる.

$$
A_{u}=\frac{1}{\alpha N}
$$

(7)式を(3)式に代入し変形すると次式となる.

$$
Q_{g}=\left(\frac{S_{g}}{\alpha N}\right)^{N}
$$

これらはN值が100から10 50範囲で近似して得られた式

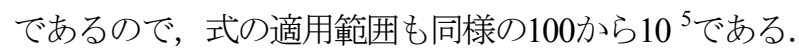

表-5および表-6から $N$ 值が 100 と $10{ }^{5}$ のときのADREを比 較すると， $10^{5}$ の方が $A D R E$ 僅かに小さく精度は良いが, 


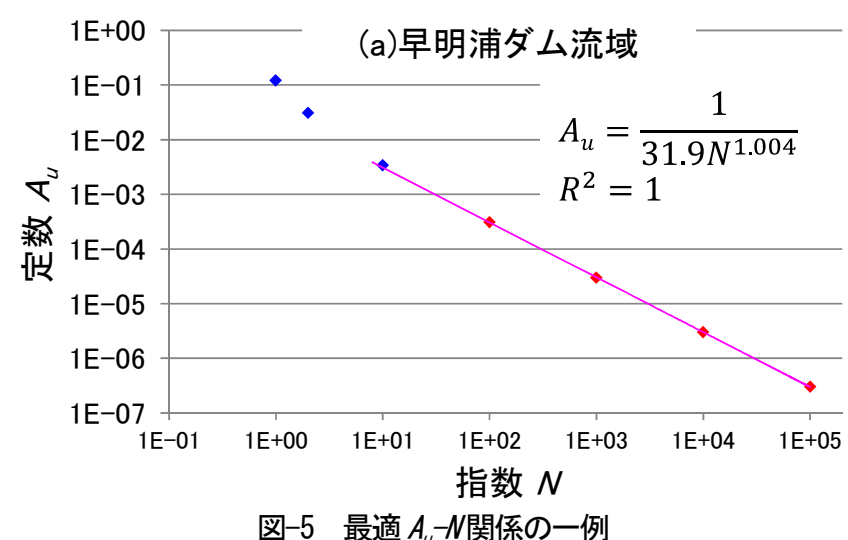

表-7 対象流域の定数 $\alpha$ と $\beta$ の值と相関係数 $R^{2}$

\begin{tabular}{|c|c|c|c|c|}
\hline & 早明浦ダム & 瀬戸川流域 & 白川ダム & 寒河江ダム \\
\hline$\alpha$ & 31.9 & 71.4 & 39.5 & 83.3 \\
\hline$\beta$ & 1.004 & 1 & 1.005 & 1 \\
\hline$R^{2}$ & 1 & 1 & 1 & 1 \\
\hline
\end{tabular}

実質的には $N$ 值は 100 も $10^{5}$ も同程度の解析精度である.

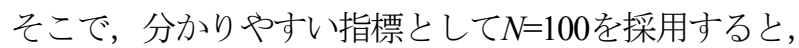
実用可能性のある次式が提案できる.

$$
Q_{g}=\left(\frac{S_{g}}{100 \alpha}\right)^{100}
$$

ここで(9)式について考察を行う。まず，N值に着目する と，(9)式は $N$ 值が100で高位の值であり, 流出量 $Q_{g}$ は貯 留量 $S_{g}$ に対して非常に感度の高い式である. しかし, 適 切な $\alpha$ 值を用い, 連続した貯留量 $S_{g}$ が得られていれば, 流出量の計算值 $Q_{g}$ は発散しないことが水循環解析の結果 から推察される. 結果的には最適定数 $\alpha$ の值によって妥 当な $Q_{g}$ が算出されているが, $S_{g}$ の変化量と $\alpha$ 值との関係 は重要であり, 今後の検討が必要である. 次に, $a$ 值に 着目すると， $\beta=1$ と見なしたことにより定数 $\alpha$ は貯留関 数式で減水性を表す唯一の定数となった. 本研究で得ら れた各流域の $\alpha$ 值を表-7に示寸，早明浦ダム流域と瀬戸 川流域の值は，それぞれ31.9と71.4である．瀬戸川流域 は早明浦ダム流域内にあり，気候，地質はほぼ同じであ るが $\alpha$ 值は異なる. また，白川ダム流域と寒河江ダム流 域の值は，それぞれ39.5 と83.3である。両流域とも同じ 気候区の積雪域にあるが $\alpha$ 值が異なる. 低水流出の規定 要因として地質の有意性を虫明ら $\left.{ }^{14}\right)$ は述べており, 高橋 $5^{15)}$, 安藤 ${ }^{16)}$, 横尾 $~^{17)}$ も低水流出の影響要因として 地質に言及している。しかし本研究の結果からは，定数 $\alpha$ に影響する要因を特定することはできなかった， $\alpha$ 值 には，地質，気候，あるいはモデル内の他の定数との干 渉など, 様々な要因が影響しているものと思われる.

\section{(3) 流況曲線の実測値と解析値の比較}

解析結果の一例として早明浦ダム流域について地下水 流出量計算值とハイドログラフの実測值と計算值を図-6 に示寸. 地下水流出量は総流出量と比較して小さいハイ ドログラフであるが，強い降雨に対して敏感に反応して

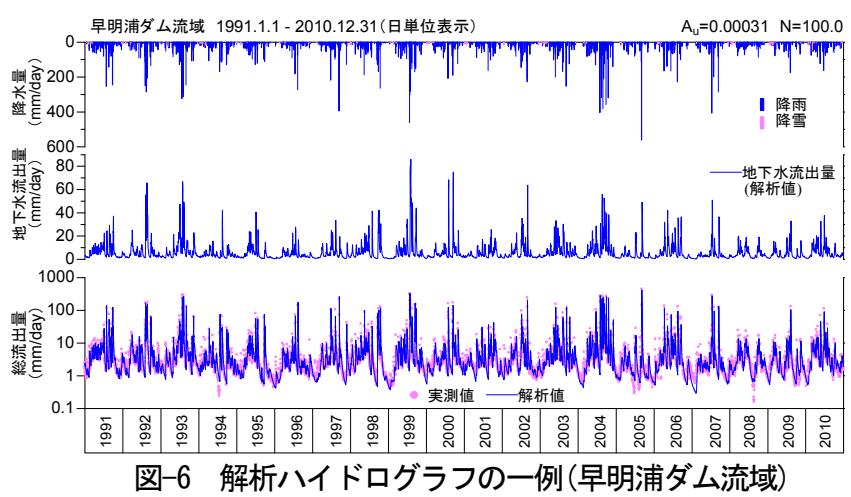

いることが分かる．流況曲線の実測值と解析値の比較を 図-7に示寸. 解析值は水循環解析を行い, 従来型の指数 $N=2$ とした貯留関数式(2)式で得られた流況曲線と, 指数 $N=100$ として提案した(9)式の貯留関数式で得られた流況 曲線である. なお， $A_{u}$ 值はそれぞれの $N$ 值に対する最適 值を用いている。 また，最低流量付近の実測值の急激な 低下は，データ欠測等の理由による．流況曲線の解析値 と実測值との比較では，使用した $N$ 値や流域の違いに よって特徴が異なる. しかし，4流域で共通しているの

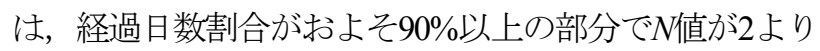
も100の方が適合性がよい，個々の流域で見ると，早明 浦ダム流域の場合は, $N=100$ の方が $N=2$ より全体的に解 析値は実測值に適合している. 瀬戸川流域では, 経過日 数 $10 \%$ 程度までは固定堰による導水量であるため, 流出 高は7.08mm/dayであり流況は一定となっている. 寒河江 ダム流域の流況曲線は, 経過日数の最初から $50 \%$ 程度ま で，解析值は実測值に対してズレが生じている．これは 先にも述べたように，表-2に示す 10 年間の年水収支にお いて，年流出量が年降水量を上回る現状から，流域外か ら浸入量の存在の可能性が要因として考えられる.

\section{5. まとめ}

前報1)では, 低水流出の貯留関数式 $Q_{g}=A_{u}{ }^{N} S_{g}^{N}$ にお ける定数 $A_{u}$ と指数 $N$ の最適值は, $A_{u}$-Nの指数関数上に現 れることを述べた. 本研究ではその指数関数に含まれる $2 つ の$ 定数 $\alpha$ と $\beta$ の特性について検討した. 地質, 気候の 異なる4流域において，N值を 1 から $10{ }^{5}$ の範囲で6つの值 を選択し，試算によって定めた範囲で $A_{u}$ を変化させなが ら水循環解析を行い, 日流出量相対誤差の平均值 $A D R E$ が最小值になる $A_{u}$ を探索した. 探索範囲を拡大させ，水 循環解析の計算数を減らすことができた. 解析結果は前 報と同様に, $A_{u}-N$ 関係は指数関数式で表された. そし て，指数関数式に含まれる $\beta$ 值を 1 と見な寸ことで， $A_{u}$ は Nの反比例式として表現できた. さらに指数Nについて 解析精度上問題ない指標値として100を設定し, 実用可 能性のある貯留関数式を提案した. 本研究では貯留関数 式の定数の感度分析を行い, 最適定数の特徵を示した. 水理学的考察など理論的裏付けは今後の課題とする. 

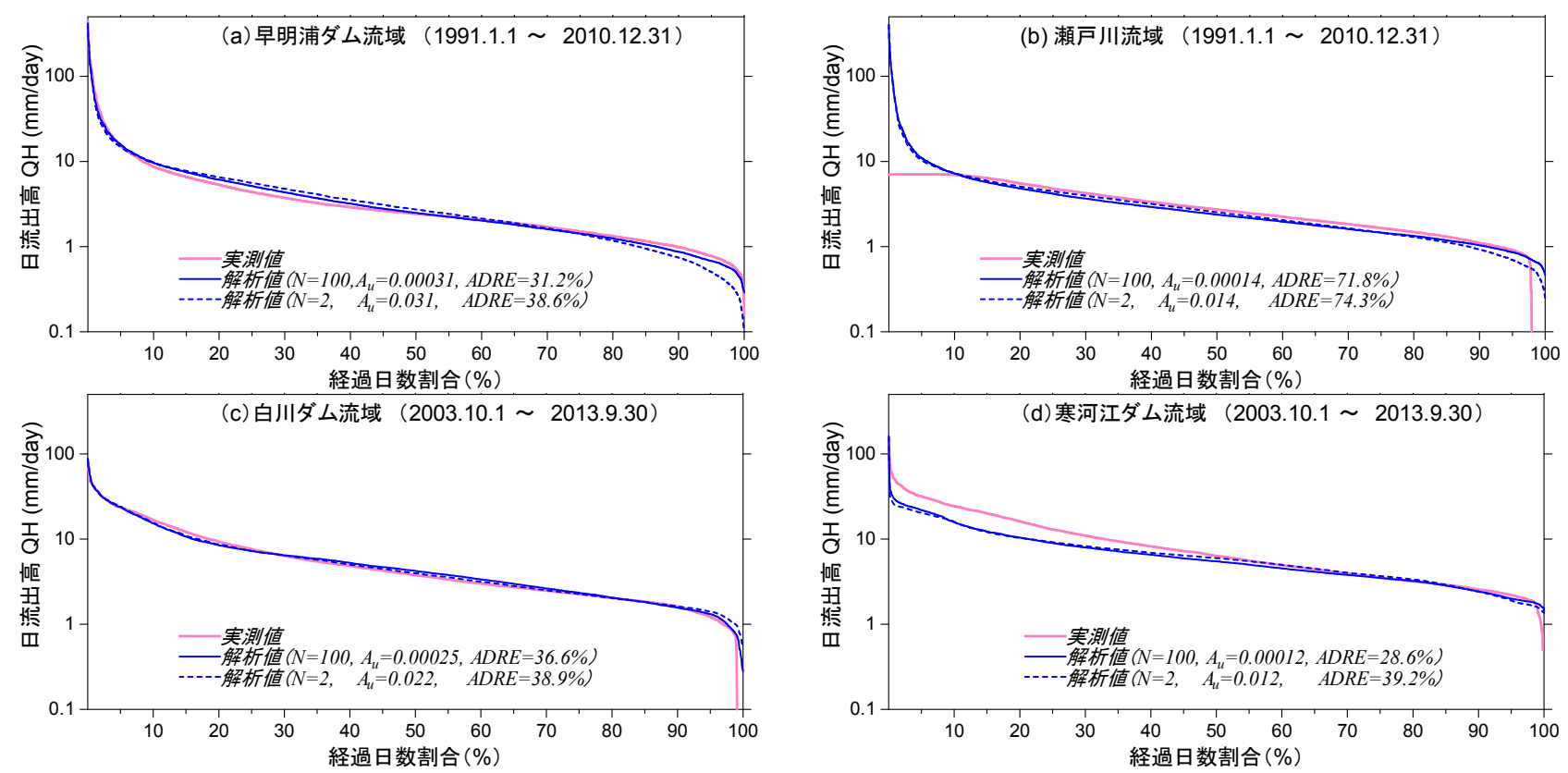

図-7 流況曲線の実測値と解析値

謝辞 : 本研究は，独立行政法人水資源機構吉野川局，池 田総合管理所から早明浦ダム流域の水文データを提供し て頂いた. また，文部科学省気候変動適応研究推進プロ グラム(RECCA)の研究課題「流域圈にダウンスケーリン グした気候変動シナリオと高知県の適応策」の成果の一 部である. 関係各位にここに記して感謝の意を表する.

\section{参考文献}

1) Hall, F. R.: Base flow recessions - a review. Water Resour. Res., 4 (5), pp.973-983, 1968.

2) Boussinesq, J.: Essai sur la théorie des eaux courantes. Mémoires présentés par divers savants à l'Académie des Sciences de l'Institut de France, Tome XXIII, No. 1, pp.1-660, 1877. (Cite by Hall (1968).)

3) Horton, R. E.: Natural stream channel-storage. Transactions, American Geophysical Union, 17(2), pp.406-415, 1936.

4) Ding, J. Y.: Discussion of "Inflow hydrographs from large unconfined aquifers" by Ibrahim, H. A. and Brutsaert, W., J. Irrig. Drain. Div., ASCE, 92, pp. 104-107, 1966.

5) Wittenberg, H. : Nonlinear analysis of low flow recession curves, FRIEND: Flow Regimes from International and Experimental and Network Data, IAHS Publ., 221, pp.61-67, 1994.

6) Tallaksen, L. M. : A review of baseflow recession analysis, $J$. Hydrology, 165, pp.349-370, 1995.

7) 安藤義久・高橋裕 : 山地河川の長期流出解析に関する一考 察, 土木学会論文報告集, 第 318 号, pp.93-105, 1982.

8) 安藤義久 - 知久岳史 - 安池宏之: 山地流域の積雪 - 融雪モ デルを含む日単位の長期流出解析，水文・水資源学会誌， 第 1 巻 1 号, pp.69-74, 1988.

9) Ding, J.Y.: A measure of watershed nonlinearity: interpreting a variable instantaneous unit hydrograph model on two vastly different sized watersheds, Hydrol. Earth Syst. Sci., 15, pp.405-423, doi:10.5194/hess-15-405-2011, 2011.

10) Fujimura, K., Shiraha, K., Kanae, S. and Murakami, M.:

Development of the hourly hydrological model for mountainous basins using the storage function method and the Diskin - Nazimov infiltration model, In: Models - Repositories of Knowledge, IAHS Publ., 355, pp.338-344, 2012.

11) 藤村和正・井芹慶彦・鼎信次郎・村上雅博 : 水循環解析に 基づく低水流出の貯留関数式における最適定数に関する研 究，土木学会論文集 B1（水工学），Vol.70, No.4，I_361I_366, 2014.

12) Fujimura, Y., Iseri, K., Kanae, S. and Murakami, M.: Identification of low-flow parameters using hydrological model in selected mountainous basins in Japan, In: Evolving Water Resources Systems: Understanding, Predicting and Managing Water-Society Interactions, IAHS Publ., 364, pp.51-56, 2014.

13) Smakhtin, V.U.: Low flow hydrology: a review, J. Hydrology, 240, pp.147-186, 2001.

14) 虫明功臣・高橋裕・安藤義久 : 日本の山地河川の流況に及 ぼす流域の地質の効果, 土木木学会論文報告集, 第 309 号, pp.51-62, 1981.

15) 高橋裕 - 安藤義久 伊藤孝 $\cdot$ 伊藤和央 : 山地河川の低水流 出の減水特性に関する研究, 土木学会論文報告集, 第 337 号, pp.75-82, 1983.

16) 安藤義久 - 高橋裕 - 伊藤和央 : 低水流出の分数関数减水式 の地質・季節要因による総合化，土木学会論文集，第 357 号, pp.149-157, 1985.

17) 横尾善之・沖大幹 : 山地河川の流況曲線形状を説明するた めの表層地質の分類法に関する検討, 水工学論文集, 第 53 巻, pp.463-468, 2009. 